\title{
Doubt cast over tiny stem cells
}

\section{Studies refute the existence of very small embryonic-like cells endorsed by the Vatican.}

\section{BY ALISON ABBOTT}

$\mathrm{D}$ oes a rare and minuscule cell type with the potential to repair almost any tissue in the body really exist?

Proponents of very small embryonic-like cells (VSELs) extracted from bone marrow say that the cells have the potential to transform regenerative medicine. A trial has begun in Poland, and cell-therapy company Neostem in New York is planning another in Michigan.

But in a major blow to the field, a paper published on 24 July in Stem Cell Reports suggests that the diminutive stem cells are not real ${ }^{1}$. Led by Irving Weissman, a prominent stem-cell researcher at Stanford University in California, the study is the fourth to refute the cells' existence - and the most thorough yet.

"Weissman's evidence is a clincher - it is the end of the road for VSELs," believes Rüdiger Alt, head of research at Vita 34, a private bank for umbilical cord blood in Leipzig, Germany, who last year published the first failure to replicate claims for the cells ${ }^{2}$.

Robin Smith, chief executive at Neostem, disagrees. She compares the attacks on VSELs to those suffered by Charles Darwin and Nicolaus Copernicus when they proposed their world-changing scientific theories.

The battle over VSELs has been raging for more than two years, and has covered ground from the United States to Vatican City and Poland. The cells were first described ${ }^{3}$ in mouse bone marrow in 2006, by a team led by Mariusz Ratajczak at the University of Louisville in Kentucky. His group and a few others have since generated a literature that characterizes VSELs as rare components of bone marrow and other tissues, less than 6 micrometres in diameter and able to turn into a diverse range of cell types, including blood, bone, muscle and nerve.

Ratajczak was given a joint position at the Pomeranian Medical University in Szczecin, Poland, in 2006. From there, he obtained $€ 10.6$ million (US $\$ 14$ million) from European Union sources for a VSEL research network involving five institutions. The network last year registered the first human trial of a VSEL preparation, which aims to treat 60 people who have severe angina. Around one-quarter of the participants have already been injected with the preparation.

But the network became rattled after one collaborator, Józef Dulak at the Jagiellonian University in Krakow, failed to find traces of VSELs

controversial Italian stem-cell trial, see: go.nature.com/b3ufcm

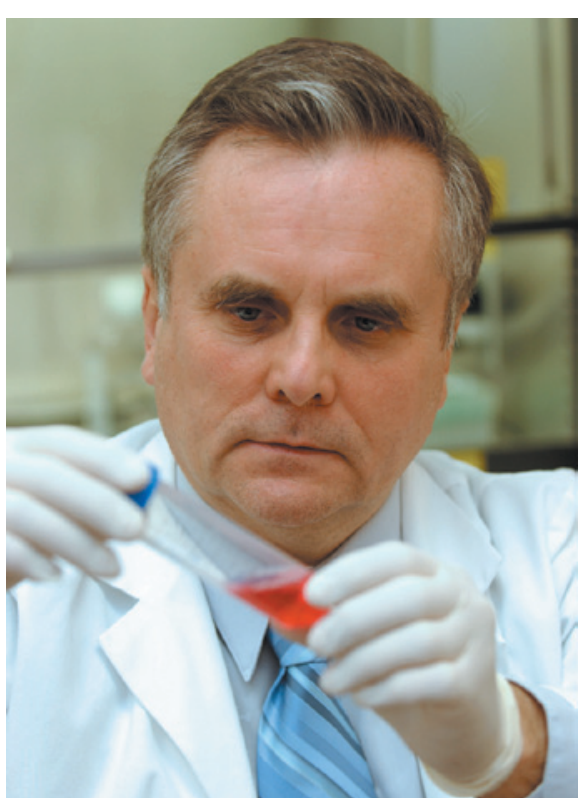

Mariusz Ratajczak first reported finding very small embryonic-like stem cells in 2006.

in his experiments. When he published his findings in $\mathrm{May}^{4}$, Ratajczak tried to force him out of the consortium. Dulak, like Weissman, found no molecular signatures associated with pluripotency in any mouse bone-marrow cells smaller than 7 micrometres across. Weissman's more extensive analysis now also reports that in his experiments, the small cells did not aggregate into spheres in vitro, as pluripotent cells do; nor could they differentiate into blood cells, the adult tissues that such cells are most likely to become.

Alt, for his part, spent 18 months studying human VSELs at Leipzig University. He says that his team gave up when its chromosome analyses revealed that the objects they observed in their experiments were not proper cells. "If they had existed, Vita 34 would have been interested to try to commercialize them," he says. "We wasted a lot of time." A fourth study, which sought VSELs in blood from umbilical cords, could not show that they were pluripotent either ${ }^{5}$.

Together with the University of Louisville, Ratajczak patented his VSEL discovery. In 2007, Neostem acquired exclusive licensing rights and created its Stem For Life Foundation, which promotes adult stem cells as an ethical alternative to embryonic stem-cell therapy. Two years ago, the Vatican, which supports this approach, donated US\$1 million to the foundation - the first time it had entered a joint venture with a trading company. It has since hosted two international conferences on adult stem cells, co-organized by Stem For Life and Neostem.

Weissman presented some of his now-published results at an unrelated meeting of the Pontifical Academy of Sciences in Vatican City in April 2012. But he says he is annoyed that representatives of the Catholic Church "act as if they don't know the scientific data" and have continued to back VSELs.

"I don't see the controversy - we have seen bone grow" from VSELs in mice, says Russell Taichman, a researcher in dental medicine at the University of Michigan in Ann Arbor. Taichman will be running the Neostembacked VSEL trial, which will look for bone regrowth in dental patients. Announced in April, the trial is awaiting approval by the US Food and Drug Administration.

The leader of the Polish VESL trial is also unfazed. "Other investigators are just not managing to catch the right cells," says Wojciech Wojakowski, a cardiologist at the Medical University of Silesia in Katowice.

Diane Krause, who has published evidence that VSELs from mouse bone marrow can differentiate into lung epithelial cells ${ }^{6}$, agrees. "I can only say that we manage to see these cells," she says. "One of our postdocs went to the Ratajczak lab and learnt the technique properly."

Ratajczak thinks that all the published criticisms come down to investigators lacking the technical skill to harvest the correct cells. "Weissman has never visited my lab to witness exactly how we carry out the method," he says. Weissman counters that "science has to be reproducible, and methods described so that others can reproduce them".

Neostem itself is becoming more cautious in its statements about VSELs. In an e-mail, Smith told Nature that the company "has studies in progress to determine, with robust data, whether or not VSELs have characteristics of pluripotent cells".

The debate exemplifies problems often seen in adult stem-cell research, in which a trial can end up being based on inadequate data, says Rudolf Jaenisch, a stem-cell researcher at the Whitehead Institute for Biomedical Research in Cambridge, Massachusetts. "It's even worse when it gets the blessing of the church."

1. Miyanishi, M. et al. Stem Cell Rep. http://dx.doi org/10.1016/j.stemcr.2013.01.001 (2013).

2. Danova-Alt, R., Heider, A., Egger, D., Cross, M. \& Alt, R. PLoS ONE 7, e34899 (2012)

3. Kucia, M. et al. Leukemia 20, 857-869 (2006).

4. Szade, K. et al. PLoS ONE 8, e63329 (2013).

5. Alvarez-Gonzalez, C. et al. PLoS ONE 8, e67968 (2013).
6. Kassmer, S. H. et al. Stem Cells http://dx.doi. org/10.1002/stem.1413 (2013). 